\title{
CAREER PROGRESSION OF WOMEN EMPLOYEES IN SERVICE SECTOR: LESSONS FROM LITERATURE REVIEW
}

\section{SAHILA CHAUDHRY}

Assistant Professor, Department of Business Administration, Chaudhary Devi Lal University, Sirsa, Haryana, India

\begin{abstract}
This study throws a light on various aspects of career progression of women employees in service sector. Hundreds of research papers were searched on the topic and finally a sample of 89 research papers published between 1997 and 2020 were selected, which include 69 international studies and 20 Indian studies. The review shows that financial support and prestige, self-assessment, self-empowerment and professional role confidence are the key points of attraction for women joining the service sector. Work-life balance, less involvement in decision making, sexual harassment, absence of safety while travelling, workplace adjustment, lack of training opportunities, domestic violence, work overload, lack of gendersensitive policies, gender segregation, discriminatory policies, socio-cultural and individual differences, multiple life roles, long working hours, caring responsibilities, parental leave or child care leave, lack of professionalization, etc. are the some of the barriers faced by them in their career. Resultantly, they either resign from the jobs and stop their career or join other organization, if not financially strong or even start their own consulting business in which they balance their time for the business from home as per their comfort zone during motherhood or child care. The measures initiated at organizational level for smooth progression of women career include providing training opportunities, flexible working hours, equal rights and opportunities, conflict resolution methods, amicable working environment, appreciation, induction programs, promoting transactional, transformational and laissez-faire leadership style, etc. Policies have also been formulated in some countries under which it is mandatory to share the maternity leave between men and women to reduce the burden of child care put on women and support them to reach at senior levels in their career.
\end{abstract}

KEYWORDS: Progression, Development, Segregation, Motivation, Discrimination

Received: Jun 08, 2020; Accepted: Jun 28, 2020; Published: Sep 15, 2020; Paper Id.: IJMPERDJUN20201248

\section{INTRODUCTION}

Nowadays, the impact of modernization and economic development on the lives of women can be noticed easily. The women have broken the traditional gender segregation in various fields such as academics, labour force, public events, corporate sector, and education, etc. (Cheng \& Wu, 2016). A new stream initiated in the society i.e. equal rights and equal employment opportunities has developed a new picture in the mind of every person regarding the women rights and opportunities. Now people have made a perception that fair number of women should exist in certain professions in such a male dominated society (Sinkele \& Mupinga, 2011).

In the last century, most significant changes have been noticed by increased number of women's participation at the paid workforce. They have achieved significant progress by increasing their movements into the various occupations (Saadina, et al. 2015). But despite of these changes, different kinds of gender issues can easily be seen especially in Indian society because glass ceiling for female workers is a strong barrier that stretches back to the women to get success or to move up high in their professional lives. It has also been noticed that women 
remain at lower positions as compared to men due to less confidence and ambiguity regarding their career life (Cech et al. 2011).

Traditionally, women tend to become homemakers i.e. they find themselves suitable for only for household chores and do not intend to work outside their house premises. There exit a lot of factors such as economic, geographical, legal and constitutional, cultural, family, etc. that mark the career development of women especially in Indian society, Genderbased discrimination impedes the women to participate in important decisions of family or career and they are unable to enjoy the equality with men (Alsharif, 2018). Till date, the rules and regulations of most of the accounting associations are framed by men to cover up the leadership qualities of women resulting of which career progression of men becomes faster than women (Din et al., 2018). But with the passage of the time, several changes have taken place and the concept of double income has gained popularity. Now men and women are making combined efforts to run their houses by maintaining a balance between their organizational and individual lives (O`Connor \& Wright, 2013).

The present study is divided into various parts covering introduction, objectives, data and methodology, classification of literature, findings and observations, suggestions, conclusion and implications of the study.

\section{RESEARCH OBJECTIVES}

The purpose is to recognize the reasons of joining the service sector by women, barriers faced by them and measures initiated for overcoming those barriers as mentioned by the earlier researchers in their studies through the review of research work published in the area during the period under study.

\section{METHODOLOGY}

In this study, the dynamics of research work published on various aspects of career progression of women in service sector will be presented. Hundreds of research papers were collected and finally reduced to 89 to achieve the objective of the study, which include 20 (22.47 percent) Indian studies and 69 (77.53 percent) international studies published from 1997 to 2020. At the end, collected data were analyzed and presented in tables to draw conclusions. The findings of the study will bring out a contrast between national and international studies of women employees about various aspects of their career progression.

\section{Classification of Literature}

The available literature is divided into different categories by using parameters like countries, years and tools used for data analysis.

\section{Country-Wise Classification}

The country-wise classification (Table-1) of the study shows that most of the researches have been conducted in USA, India and UK. Out of total eighty nine research papers, twenty three are from USA, twenty from India, thirteen from UK, seven from Europe, six from Australia and three each from Malaysia, Netherland and Saudi Arabia. Other countries like Iran, Thailand, East Africa, Canada, Korea, Singapore, etc. also took initiative in the stream.

Table 1: Country-Wise Classification

\begin{tabular}{|c|c|c|c|l|c|}
\hline S. No. & Country & No. of Studies & S. No. & Country & No. of Studies \\
\hline 1 & USA & 23 & 11 & East Africa & 01 \\
\hline 2 & India & 20 & 12 & Canada & 01 \\
\hline
\end{tabular}




\begin{tabular}{|c|c|l|l|l|l|}
\hline 3 & UK & 13 & 13 & Korea & 01 \\
\hline 4 & Europe & 07 & 14 & Singapore & 01 \\
\hline 5 & Australia & 06 & 15 & Nigeria & 01 \\
\hline 6 & Malaysia & 03 & 16 & South Africa & 01 \\
\hline 7 & Netherland & 03 & 17 & New Zealand & 01 \\
\hline 8 & Saudi Arabia & 03 & 18 & China & 01 \\
\hline 9 & Iran & 01 & 19 & Nepal & 01 \\
\hline 10 & Thailand & 01 & & Total & 89 \\
\hline
\end{tabular}

Source: Compiled from earlier studies.

\section{Year-Wise Classification}

Table 2shows the research work conducted in this area, which gained popularity after the year of 2010 as lot of researches have been conducted in this field during the year 2011 and afterwards.

Table 2: Year-Wise Classification

\begin{tabular}{|c|c|c|c|c|c|}
\hline S. No. & Year & Frequency & S. No. & Year & Frequency \\
\hline 1 & 1997 & 01 & 13 & 2010 & 02 \\
\hline 2 & 1998 & 02 & 14 & 2011 & 06 \\
\hline 3 & 2000 & 01 & 15 & 2012 & 04 \\
\hline 4 & 2001 & 02 & 16 & 2013 & 07 \\
\hline 5 & 2002 & 01 & 17 & 2014 & 08 \\
\hline 6 & 2003 & 04 & 18 & 2015 & 05 \\
\hline 7 & 2004 & 03 & 19 & 2016 & 05 \\
\hline 8 & 2005 & 06 & 20 & 2017 & 04 \\
\hline 9 & 2006 & 03 & 21 & 2018 & 04 \\
\hline 10 & 2007 & 03 & 22 & 2019 & 09 \\
\hline 11 & 2008 & 03 & 23 & 2020 & 01 \\
\hline 12 & 2009 & 05 & & Total & 89 \\
\hline
\end{tabular}

Source: Compiled from earlier studies.

\section{Analysis-Wise Classification}

Table-III reveals the tools and techniques used to analyze the data in earlier studies like correlation analysis, regression analysis, percentage analysis, factor analysis, ANOVA, etc. to achieve the objectives of their studies. It is also noticed that correlation analysis, regression analysis and percentage analysis have been used in higher frequency as compared to other tools.

Table 3: Analysis-Wise Classification

\begin{tabular}{|l|c|}
\hline \multicolumn{1}{|c|}{ Tools used for Data Analysis } & Frequency \\
\hline Regression Analysis & 21 \\
\hline Correlation Analysis & 18 \\
\hline Percentage Analysis & 12 \\
\hline Comparative Analysis & 10 \\
\hline Factor Analysis & 11 \\
\hline ANOVA & 08 \\
\hline t-test & 02 \\
\hline Feminist Theory & 02 \\
\hline Longitudinal Analysis & 01 \\
\hline Thematic Analysis & 01 \\
\hline Constructivist grounded theory approach & 01 \\
\hline Person categorization and Social role theories & 01 \\
\hline Charting Process, Discourse Analysis and Life History Analysis & 01 \\
\hline Source Compiled from & \\
\hline
\end{tabular}

Source: Compiled from earlier studies. 


\section{Findings and Observations}

The review of literature shows that a large number of international studies (Susan \& Imhoff 1997, Lyness \& Thompson 2000, Adams et al., 2003, Fuller \& Narasimhan 2007, Hoobler et al., 2009, Tlaiss \& Kauser 2010, Jogulu \& Wood 2011, Dezso \& Ross 2012, Ellemers 2014, Andric 2015, Saadin et al,. 2016, Pringle et al., 2017, Alsharif 2018), etc. have been conducted on career progression of women employees and these are more than the Indian studies (Parikh \& Sukhatme 2004, Patel \& Parmentier 2005, Tara \& Ilavarasan 2009, Juliet \& Vijila 2011, Gupta 2012, Rawat 2014, Rath et al,. 2015, Chawla \& Sharma 2016, Datta \& Agarwal 2017, Kapur 2018, Khattar 2019), etc.

Susan \& Imhoff (1997), Lyness \& Thompson (2000), Adams et al. (2003), Fuller \& Narasimhan (2007), Hoobler et al. (2009), Cech et al. (2011), Singh \& Fouad (2013), Ravindran \& Baral (2014), Chawla \& Sharma (2016), Datta \& Aggarwal (2017), Rangarajan, (2018), Makarova et al. (2019), etc. focused on the reasons which encouraged the women to join service sector like financial support (Parikh \& Sukhatme, 2004, Datta \& Aggarwal, 2017), prestige (Kandiko, 2017), self efficacy (Singh \& Fouad, 2013), advancement (Lyness \& Thompson, 2000), enthusiasm and career mobility (Susan \& Jennifer, 2010, Gupta 2012), equity (Khoreva, 2011), maintaining work-life balance (Rangarajan, 2018), improvement in socio-cultural and political status (Patel \& Parmentier, 2005), generating leadership qualities (Mattis, 2001), career success (Kim, 2004), professional role confidence (Cech et al., 2011), self-assessment, creating gender equality (Chawla \& Sharma, 2016), self efficacy and task value among others (Geigner \& Crow, 2014), etc. In the ancient time, these reasons were the source of attraction for men only, but now the women also join service sectors due to these reasons (Klatt et al., 2016). However, self-assessment (Cech et al., 2011), self-empowerment (Devi, 2017) and professional role confidence are the main points of attraction outside India for women joining the service sector (Cech et al., 2011).

Payne (1998), Eagly \& Schmidt (2001), Powell \& Butterfield (2003), Knorr (2005), Foster et al. (2007), Sipe et al. (2009), Tlaiss \& Kauser (2010), Juliet \& Vijila (2011), Gupta (2012), Ellemers (2014), Marinelli (2015), Wu \& Cheng (2016), Devi (2017), Alsharif (2018), Kapur (2019), etc. paid attention on the blockades that Indian women faced throughout their career such as work-life balance, gender stereotype (Saadin et al., 2015), peer pressure, lack of family support, occupational stress, perception of roles and abilities of women, less involvement in decision making (Thanacoody et al., 2006), sexual harassment, absence of safety while travelling, workplace adjustment, lack of training opportunities, domestic violence (Khattar, 2019), work overload, lack of gender-sensitive policies (Fuller \& Narasimhan, 2007), etc. Due to these barriers, they resign from jobs and join some other organization, if not financially strong. It has also been found that few Indian women have also raised their voice against the harassment, discrimination and exploitation (Chawla \& Sharma, 2016).

On the other hand, gender segregation, discrimination in policies by government and employers, socio-cultural and individual differences (Trauth et al., 2008), multiple life roles (Phillips \& Imhoff, 1997), long working hours and caring responsibilities, less confidence (Hadfield \& Sen, 2014), parental leave/family related or child care leave (John Evans, 2001), lack of professionalization (Joseph et al., 2005), lack of confidence and career immobility (Arun et al., 2014), absence of comprehensive development plan, reward and incentives and inappropriate income (Alsharif, 2018) are some of the barriers being faced by women in other countries. Due to these barriers, they either join training and development programs (Thanacoody et al., 2006) or start their own consulting business (Ranson, 2003) in which they balance their time for the business from home as per their comfort zone. 
Payne (1998), Kelkar et al. (2002), Arun et al. (2004), O'Leary \& Deegan (2005), Fuller \& Narasimhan (2007), Sipe et al. (2009), Juliet \& Vijila (2011), Gupta \& Saran (2013), Rawat (2014), Yadav \& Unni (2016), Nabanita \& Chatterjee (2017), Khattar (2019), etc. highlighted the measures initiated for smooth career progression of Indian women employees. The organizational level measures include providing training opportunities (Alsharif, 2018), employee motivation, flexible working hours (Hadfield \& Sen, 2014), performance appraisal methods, equal rights and opportunities (Wu \& Cheng, 2016), conflict resolution methods, amicable working environment (Din et al., 2018) appreciation, induction programs (Kapur, 2019), etc. Government has also initiated various labour reforms to improve the situation of women and promote their entry in service sector (De \& Chatterjee, 2017, Devi, 2017), etc. Further, efforts were also made for creating larger freedom for women, improving health and education indicators for women, reducing the occurrence of violence against women and providing quality services to the victims (De \& Chatterjee, 2017).

On the other hand, for improving their smooth career development outside India, organizations have decided to increase advertisements featuring only women, particularly in computer or engineering magazines and to create informal networks with females that will provide the information regarding job opportunities to them (Sinkele \& Mupinga, 2011). Various encouragement activities have been conducted by the organizations of United States to attract the women in service sector (Geigner \& Crow, 2014). Efforts were also made to bridge the gap between employers and educators so that they can provide enough access to female students at the time of recruitment. It helps the organizations to find out the talented students by internships and apprenticeships (Sinkele \& Mupinga, 2011). Organizations are also promoting transactional, transformational and laissez-faire leadership style to attract women towards the service sector (Eagly et al. 2001). Some educational institutions also paid focus to increase the role of teacher in the life of a student for encouragement (Adams et al., 2005). In some developed countries, government has decided the share of women in leadership positions (Alsharif, 2018) and to create gender equality in labour market. Policies have also been formulated under which it is mandatory to share the maternity leave between men and women i.e. family leave policies for both men and women ( $W u$ \& Cheng, 2016) to reduce the burden of child care put on women and support them to reach at the senior positions in career (O`Connor \& Wright, 2013).

\section{SUGGESTIONS}

As India is moving towards next level with its gender diversity, there is a need to avoid socio-cultural and psychological barriers which create a lot of hurdles in the progress of the society as whole (Datta \& Aggarwal, 2017). In fact, empowerment is a key which divide the whole world into two parts such as developed and developing worlds (Khattar, 2019). When the issue of women employability is addressed, then a lot of questions arises in Indian society demanding sustainable development, which is possible only when the present status of the women is improved (Alsharif, 2018). And so far the growth of any organization or society as a whole is concerned, there is a need to focus on fair treatment without discrimination on the gender basis, formulating strict policies regarding sexual harassment, equal opportunities for promotion, etc. (Wu \& Cheng, 2016). On other side, men should also take the responsibility of child care and must share all the household chores (Hadfield \& Sen, 2014). Sometimes, women break their career chain by resigning from the jobs thinking that they will not be able to utilize their full potential due to burden of family responsibilities (Kapur, 2019). Therefore, proper family support is required for maintaining a balance in their work and professional life so that they may prosper in their career (Saddin et al., 2015). The educational institutions and employers should try to develop different kind of interacting programs with the students as well as with their parents to create awareness regarding the rights available to 
the girl child (Trauth et al. 2008). The government should initiate strict actions against those private organizations which do not pay to female workers for their maternity leave (O'Connor \& Wright, 2013). The organizations should also try to improve the role of the women in the organizations by paying more attention on fairness and in accessing all sorts of facilities for employees regardless of gender (Bartram et al. 2006). The role of women should be increased in decisionmaking, whether in personal life or professional life to ensure gender equality in the society (Din et al., 2018). If Indian women want to crack the ceiling and want to see the blue sky of freedom, then efforts are required at each and every level because women's personal empowerment cannot be productive without collective empowerment (Nabanita \& Chatterjee, 2017).

\section{CONCLUSIONS}

Despite the barriers like organizational, economic, geographical, legal and constitutional, cultural, family, etc. faced by women in their career, they are prospering in various fields and even registered a great dominance in some streams. The findings of the study exhibit that UK, India and USA took more initiative in examining this issue. However, later on, some other countries too like Thailand, East Africa, Canada, Korea, Singapore, Iran, etc. have also taken initiative in the stream. Now government as well as organizations in all the countries is making sincere efforts for the betterment of women in the society.

\section{Implications of the Study}

This study will present an organized view of empirical studies in career progression of women in service sector. It will also offer a base to future researchers to pursue their research work in the respective field. After analyzing the barriers faced by the women and measures initiated for their career advancement, this study will provide a roadmap to the employers for policy making about the different issues involved in career progression of women.

\section{REFERENCES}

1. Adya, M. P. (2008). Women at Work: Differences in IT Career Experiences and Perceptions between South Asian and American Women. Human Resource Management, 47 (3), 601-635, ISSN: 2331-0715

2. Arun, S. V. \& Arun, T. G. et al. (2004). The Effect of Career Breaks on the Working Lives of Women. Feminist Economics, 10 (1), 65-84., ISSN: $1466-4372$

3. Budhwar, P. S. \& Saini, D. S. (2005). Women in Management in the New Economic Environment: The Case of India. Asia Pacific Business Review, 11(2), 179-193, ISSN: 1360-2381

4. Cech, E. \& Rubineau, B. et al. (2011). Professional Role Confidence and Gender Persistence in Engineering. American Sociological Review, 76 (5), 641-666, ISSN: 1939-8271

5. Chawla, S. \& Sharma, R. R. (2016). How Women Traverse an Upward Journey in Indian Industry: Multiple Case Studies. Gender in Management: An International Journal, 31 (3), 181-206, ISSN: 1754-2413

6. Chovwen, C. (2007). Barriers to Acceptance, Satisfaction and Career Growth Implications for Career Development and Retention of Women in Selected Male Occupations in Nigeria. Women in Management Review, 22 (1), 68-78, ISSN: 0964-9425

7. Durbin, S. \& Tomlinson, J. (2010). Female Part-Time Managers: Networks and Career Mobility. Work, Employment \& Society, 24 (4), 621640, ISSN: 09500170

8. Eagly, A. H. \& Johannesen, M. C. (2001). The Leadership Styles of Women and Men. Journal of Social Issues, 57(4), 781-797, ISSN: 15404560 .

9. Foster, C. \& Whysall, P. et al. (2007). Female Career Progression in Retailing. International Journal of Retail \& Distribution Management, 
35 (12), 975-981, ISSN: 0959-0552

10. Fuller, C. J., \& Narasimhan, H. (2007). Information Technology Professionals and the New-Rich Middle Class in Chennai (Madras). Modern Asian Studies, 41 (01), 121-150, ISSN: 1469-8099

11. Geigner, C. L., \& Crow, G. B. (2014). A Comparison of Job Satisfaction among Women in Computing and a more Traditional Female Occupation. Communications of the IIMA, 3 (1), ISSN: 1543-5970

12. Gupta, V. \& Saran, A. (2013). Making of the Trendsetter Generation of Women Leaders in India: Dimensionalizing the Impact of Economic Liberalization. IUP Journal of Business Strategy, 10 (2), 7-21, ISSN: 0972-9259

13. Gupta, N. (2012). Women Undergraduates in Engineering Education in India: A Study of Growing Participation. Gender Technology and Development, 16 (2), ISSN: 09718524

14. Hoobler, J. M. \& Wayne, S. J. (2009). Bosses' Perceptions of Family-Work Conflict and Women's Promotability: Glass Ceiling Effects. Academy of Management Journal, 52 (5), 939-957, ISSN: 1948-0989

15. Ismail, M. (2003). Men and Women Engineers in a Large Industrial Organization: Interpretation of Career Progression Based on Subjective Career Experience. Women in Management Review, 18 (1/2), 60-67, ISSN: 0964-9425

16. Jamali, R. \& Nejati, M. (2009). Women's Career Progression Barriers and Organisational Justice: A Study of Iranian Society. Business Strategy Series, 10 (5), 311-328, ISSN: 1751-5637

17. Jogulu, U. \& Wood, G. (2011). Women Managers' Career Progression: An Asia Pacific Perspective. Gender in Management: An International Journal, 26 (8), 590-603, ISSN: 1754-2413

18. Joseph, D. (2005). Identifying the Prototypical Career Paths of IT Professionals: A Sequence and Cluster Analysis. Proceedings of the 2005 ACM SIGMIS CPR Conference on Computer Personnel Research, accessed from http://dl.acm.org on June 15, 2020 at 8:00 am

19. Juliet Gladies, J. \& Kennedy, V. (2011). Impact of Organisational Climate on Job Stress for Women Employees in Information Technology Sector in India. Asia Pacific Journal of Research in Business Management, 2 (6), ISSN: 2229-4104

20. Kelkar, G. \& Shrestha, G. et al. (2002). IT Industry and Women's Agency: Explorations in Bangalore and Delhi, India. Gender, Technology and Development, 6 (1), 63-84, ISSN: 0973-0656

21. Khoreva, V. (2011). Gender Pay Gap and its Perceptions. Equality, Diversity and Inclusion. An International Journal, 30 (3), 233-248, ISSN: 0883-0355

22. Kim, N. (2004). Career Success Orientation of Korean Women Bank Employees. Career Development International, 9 (6), 595-608, ISSN: $1362-0436$

23. Klatt, J. \& Eimler, S.C. et al. (2016). Makeup Your Mind: The Impact of Styling on Perceived Competence and Warmth of Female Leaders. Journal of Social Psychology, 156(5), 483-497, ISSN: 1940-1183

24. Lyness, K. S. \& Thompson, D. E. (2000). Climbing the Corporate Ladder: Do Female and Male Executives Follow the Same Route? Journal of Applied Psychology, 85 (1), 86, ISSN: 1939-1854

25. Mattis, C. (2001). Advancing Women in Business Organizations: Key Leadership Roles and Behaviour of Senior Leaders and Middle Managers. Journal of Management Development, 20 (4), 371-388, ISSN: 0262-1711

26. McIntosh, B. \& McQuaid, R. et al. (2012). Motherhood and its Impact on Career Progression. Gender in Management: An International Journal, 27 (5), 346-364, ISSN: 1754-2413

27. O'Leary, S. \& Deegan, J. (2005). Career Progression of Irish Tourism and Hospitality Management Graduates. International Journal of Contemporary Hospitality Management, 17 (5), 421-432, ISSN: 0959-6119

28. Parikh, P. P. and Sukhatme, S. P. (2004). Women Engineers in India. Economic and Political Weekly, 39 (2), 193-201, ISSN: $2349-8846$

29. Pas, B. \& Peters, P. et al. (2011). Explaining Career Motivation among Female Doctors in the Netherlands: The Effects of Children, Views on Motherhood and Work-Home Cultures. Work, Employment \& Society, 25 (3), 487-505, ISSN: 1469-8722 
30. Patel, R., \& Parmentier, M. J. C. (2005). The Persistence of Traditional Gender Roles in the Information Technology Sector: A Study of Female Engineers in India. Information Technologies \& International Development, 2 (3), 29, ISSN: 1544-7529

31. Powell, G.N. \& Butterfield, D.A. (2003). Gender, Gender Identity, and Aspirations to Top Management. Women in Management Review, 18(1/2), 88-96, ISSN: 0964-9425

32. Rani T. P. \& Bartram, T. (2006). Career Progression among Female Academics: A Comparative Study of Australia and Mauritius. Women in Management Review, 21 (7), 536-553, ISSN: 0964-9425

33. Ranson, G. (2003). Beyond Gender Differences: A Canadian Study of Women's and Men's Careers in Engineering. Gender, Work \& Organization, 10 (1), 22-41, ISSN: 1468-0432

34. Rath, T. S. \& Mohanty, M. (2015). Career Advancement of Women Bank Managers in India: A Study in State Bank of India. XIMB Journal of Management, 12(1), 87-96, ISSN: 0973-1954

35. Ravindran, B. \& Baral, R. (2014). Factors affecting the Work Attitudes of Indian Re-Entry Women in IT Sector. Vikalpa, 39(2), 31-42, ISSN: 0256-0909

36. Schruijer, S. L. (2006). Do Women want to break the Glass Ceiling: A Study of their Career Orientations and Gender Identity in the Netherland. Management Review, 17(2), 143-154, ISSN: 09359915

37. Singh, R. \& Fouad, N. A. (2013). Stemming the Tide: Predicting Women Engineers' Intentions to Leave. Journal of Vocational Behaviour, 83 (3), 281-294, ISSN: 0001-8791.

38. Singh, V. \& Terjesen, S. (2008). Newly Appointed Directors in the Boardroom: How do Women and Men Differ? European Management Journal, 26 (1), 48-58, ISSN: 0263-2373

39. Sinkele, C. N. \& Mupinga, D. M. (2011). The Effectiveness of Engineering Workshops in Attracting Females into Engineering Fields: A Review of the Literature. The Clearing House: A Journal of Educational Strategies, Issues and Ideas, 84 (1), 37-42, ISSN: 0009-8655

40. Sipe, S. \& Johnson, C. (2009). University Students' Perceptions of Gender Discrimination in the Work Place: Reality versus Fiction. Journal of Education for Business, 84 (6), 339-349, ISSN: 0883-2323

41. Standing, C. \& Standing, S. (1998). The Politics and Ethics of Career Progression: A Systems Perspective. Logistic Information Management, 11 (5), 309-316, ISSN: 0957-6053

42. Sweet, S. \& Sarkisian, N. et al. (2016). Are Women less Career Centric than Men? Structure, Culture, and Identity Investments. Community, Work \& Family, 19 (4), 481-500, ISSN: 1469-3615

43. Tara, S. \& Ilavarasan, P. V. (2009). I would not have been working here: Parental Support to Unmarried Daughters as Call Centre Agents in India. Gender Technology and Development, 13 (3), 385-406, ISSN: 09718524

44. Tlaiss, H. \& Kauser, S. (2010). Perceived Organizational Barriers to Women's Career Advancement in Lebanon. Gender in Management: An International Journal, 25 (6), 462-496, ISSN: 1754-2413

45. Tlaiss, H. A. (2014). Between the Traditional and the Contemporary: Careers of Women Managers from a Developing Middle Eastern Country Perspective. The International Journal of Human Resource Management, 25(20), 2858-2880, ISSN: 1466-4399

46. Towler, A. J. \& Stuhlmacher, A. F. (2013). Attachment Styles, Relationship Satisfaction, and Well-Being in Working Women. The Journal of Social Psychology, 153(3), 279-298, ISSN: 1940-1183

47. Trauth, E. M., Quesenberry, J. L., \& Huang, H. (2008). A Multi-cultural Analysis of factors influencing Career Choice for Women in the Information Technology Workforce. Journal of Global Information Management, 16 (4), 1-23, ISSN: 1062-7375

48. Vanitha, A. (2013). A Comparative Study of Quality of Work Life of Women Employees with reference to Private and Public Banks in Kanchipuram District. International Journal of Research in Commerce, IT \& Management, 3 (4), 78, ISSN: 2455-1627 